\title{
ТЕОРІЯ ТА ІСТОРІЯ ДЕРЖАВНОГО УПРАВЛІННЯ
}

УДК 351

DOI https://doi.org/10.32838/2663-6468/2019.5/01

\section{Марухленко О.В.}

Національна академія державного управління при Президентові України

\section{СВІТОВИЙ ДОСВІД В ОБЛАСТІ ІНВЕСТИЦЙНОЇ ПОЛІТИКИ}

\begin{abstract}
У статті представлені результати дослідження міжнародного досвіду в області інвестиційної політики та створення інструментів по формуванню і розвитку інвестиційного потенціалу території. Визначено вплив інструментів поліпшення інвестиційного потенщіалу на його складові елементи. Виділено позитивні і негативні сторони впливу інструментів на інвестиційну складову частину території. Аналіз державної інвестиційної політики, що проводиться в країнах із ринковою економікою, свідчить про те, щчо вона, як правило, не зводиться лише до створення загальних умов інвестиџійної діяльності, а передбачає активну роль держави у створенні системи довгострокового фінансування економіки. Багато розвинених крайн, у тому числі держави Свросоюзу, хоча і пред 'являють до іноземних держав жорсткі вимоги щодо мінімізачії державного втручання в економіку, самі проводять активну державну протекціоністську політику. Це викликано тим, що рішення низки інвестиційних завдань, поставлених державою, неминуче вимагає такого втручання. Державне фінансування економіки за кордоном здійснюється за допомогою різноманітних, у тому числі і програмно-иільових, методів і розподіляється по різних секторах економіки, для чого використовуються різні типи спеціальних державних фінансових інститутів.

В умовах невизначеності, посилення нестабільності в трендах глобального розвитку особливої актуальності набуває активізація факторів, щчо сприяють забезпеченню стійкості та конкурентоспроможності національних економік. Серед них - збільшення обсягів, раціоналізачія структури, диверсифікачія джерел, обтрунтування пріоритетних напрямів і механізмів залучення й ефективного використання інвестичійних ресурсів, які формуються в інституційних секторах украӥнської економіки та поза ї̈ межами. Сектор загального державного управління виконує в інвестииійному процесі особливі функиї - його регулятора й інвестора бюджетних коштів. Нині Україна знаходиться на шляху до євроінтегращії, що вимагає застосування актуальних у світовому масштабі підходів і пріоритетів до розвитку держсавної інвестиційної політики та формування пріоритетів державних інвестииійних видатків. Так, державна інвестиційна політика України має включати базові аспекти основних цілей та завдань інвестиційної політики нового покоління, щцо враховує останні тенденції та потреби світової економіки. Оскільки в Україні відбувається реформування економічних процесів відповідно до європейських стандартів, актуально розглянути узагальнення зарубіжного досвіту в напрямі формування та реалізації державної інвестиційної політики.
\end{abstract}

Ключові слова: інвестиційна політика, нормативно-правові акти, держава, конвенція, угода, стандарти.

Постановка проблеми. 3 метою всебічного розгляду проблематики інвестиційного механізму розвитку соціального потенціалу, на нашу думку, доцільним є звернення до міжнародного досвіду регулювання інвестиційної політики. Адже розвиток соціального потенціалу в сучасному суспільстві визначається не лише особливостями та рівнем соціального розвитку певної країни, а й досягненнями світової цивілізації загалом, рівнем інтегрованості міжнародного співтовари- ства. Дієвим інструментом, що забезпечує ефективність інтеграційних процесів інвестиційних механізмів до кращих зразків цивілізаційних надбань, є міжнародні та європейські стандарти у цій сфері. Міжнародні стандарти у сфері інвестиційної діяльності та інвестиційної політики - норми, закріплені офіційними документами міжнародних та європейських організацій.

Аналіз останніх досліджень і публікацій. Питання державного регулювання інвестицій- 
ної діяльності розглядалися в роботах О. Амоші, О. Гаврилюка, А. Гальчинського, В. Гейця, В. Зимовця, Т. Єфименко, Л. Ігоніної, М. Крупки, І. Лютого, В. Ніколаєва, В. Осецького, А. Пересади, В. Пилипіва, Р. Харрода, Д. Черваньова та ін.

Постановка завдання. Метою статті є обгрунтування шляхів забезпечення якісних змін у державній інвестиційній політиці України з урахуванням зарубіжного досвіду та розробка практичних рекомендацій щодо залучення та використання інвестиційних ресурсів.

Виклад основного матеріалу дослідження. Відповідно до процесів, що відбуваються під час інвестиційної діяльності, доцільно виділити такі структурні рівні правового регулювання інвестиційного законодавства: міжнародний (правові акти міжнародних інституцій, міжнародні угоди), національний (правові акти центральних органів державної влади), регіональний (правові акти, що регулюють інвестиційну діяльність на рівні регіонів), локальний, місцевий (правові акти місцевих органів державної виконавчої влади та акти органів місцевого самоврядування) (рис. 1).

Очевидно, що предметом регулювання міжнародного інвестиційного права $є$ специфічний комплекс суспільних відносин, учасниками яких $€$ держави й інші суб'єкти міжнародного права, спеціалізовані міжнародні інвестиційні, транснаціональні корпорації, деякі міжнародні неурядові організації, міжнародні фінансові й економічні організації та інші іноземні інвестори зі статусом юридичних і фізичних осіб.

До міжнародних нормативно-правових актів, що регулюють інвестиційну діяльність, належать: Угода про Міжнародний валютний фонд, Вашингтонська конвенція 1965 р. «Про порядок вирішення інвестиційних суперечок між державами й іноземними особами іншої держави» (ратифіковано Законом України від 16.03.2000р.), Сеульська конвенція 1985 р. «Про організацію багатостороннього агентства по гарантіях інвестицій». За матеріалами конференції було прийнято низку законів України, серед яких «Про вступ України до Міжнародного валютного фонду, Міжнародного банку реконструкції та розвитку, Міжнародної фінансової корпорації, Міжнародної асоціації розвитку та Багатостороннього агентства по гарантіях інвестицій» від 03.06.1992 р., Договори до Свропейської Енергетичної Хартії, прийняті на Першій конференції ЮНКТАД у Женеві в 1964 р., Декларація про встановлення нового міжнародного економічного порядку і Хартія економічних прав і обов'язків держав, прийняті у формі Резолюцій Генеральної Асамблеї ООН «Про заходи зміцнення довіри в міжнародних економічних відносинах» (1984 p.) i «Про міжнародну економічну безпеку» (1985р.), Угода про співробітництво в галузі інвестиційної діяльності, Конвенція про захист прав інвестора від 28.03.1997 р. До цього переліку можна також додати нормативно-правові акти, що регулюють транскордонне співробітництво.

Серед них Свропейська хартія місцевого самоврядування, Концепція міжрегіонального та прикордонного співробітництва держав-учасниць СНД, Лісабонська концепція кластерного розвитку європейських країн тощо.

Говорячи про міжнародні та європейські стандарти регулювання інвестиційної діяльності, варто зазначити, що чинні міжнародні конвенції становлять невелику частину у всеосяжному обсязі правового регулювання інвестиційної політики.

Разом із тим ті деякі міжнародні акти у сфері здійснення інвестиційної діяльності мають важливе значення, незважаючи на те, що у правовому регулюванні відіграють, скоріше, другорядне значення. Загалом слід зазначити, що міжнародноправове регулювання виступає необхідним засобом координації та діяльності держав на світовій арені, в тому числі і в регулюванні інвестиційних відносин.

Чинні міжнародні інвестиційні конвенції регулюють окремі питання. Зокрема, Вашингтонська конвенція, мета якої - міжнародний захист іноземних інвестицій, спрямована на регулювання відносин країни-реципієнта (держава, законодавство якої регулює процеси інвестування) i приватних інвесторів. Згідно з цим документом, передбачено, що судові розгляди по таких справах відбуваються не в законодавчому полі країни або в національних судових установах, а підкоряються спеціально сформованому для таких цілей органу, яким керує МБРР (Міжнародний банк реконструкції та розвитку). Ця конвенція, підписана і ратифікована Україною у 2000 р., гарантує приватним інвесторам справедливий, незаангажований розгляд спорів, пов'язаних 3 іноземними інвестиціями.

Світова практика показує, що зберігається тенденція до двостороннього та багатостороннього регулювання здійснення інвестиційної діяльності через міжнародні економічні організації, перш за все, через Світову організацію торгівлі (СОТ), Міжнародний валютний фонд (МВФ) і Міжнародний банк реконструкції і розвитку (МБРР). 


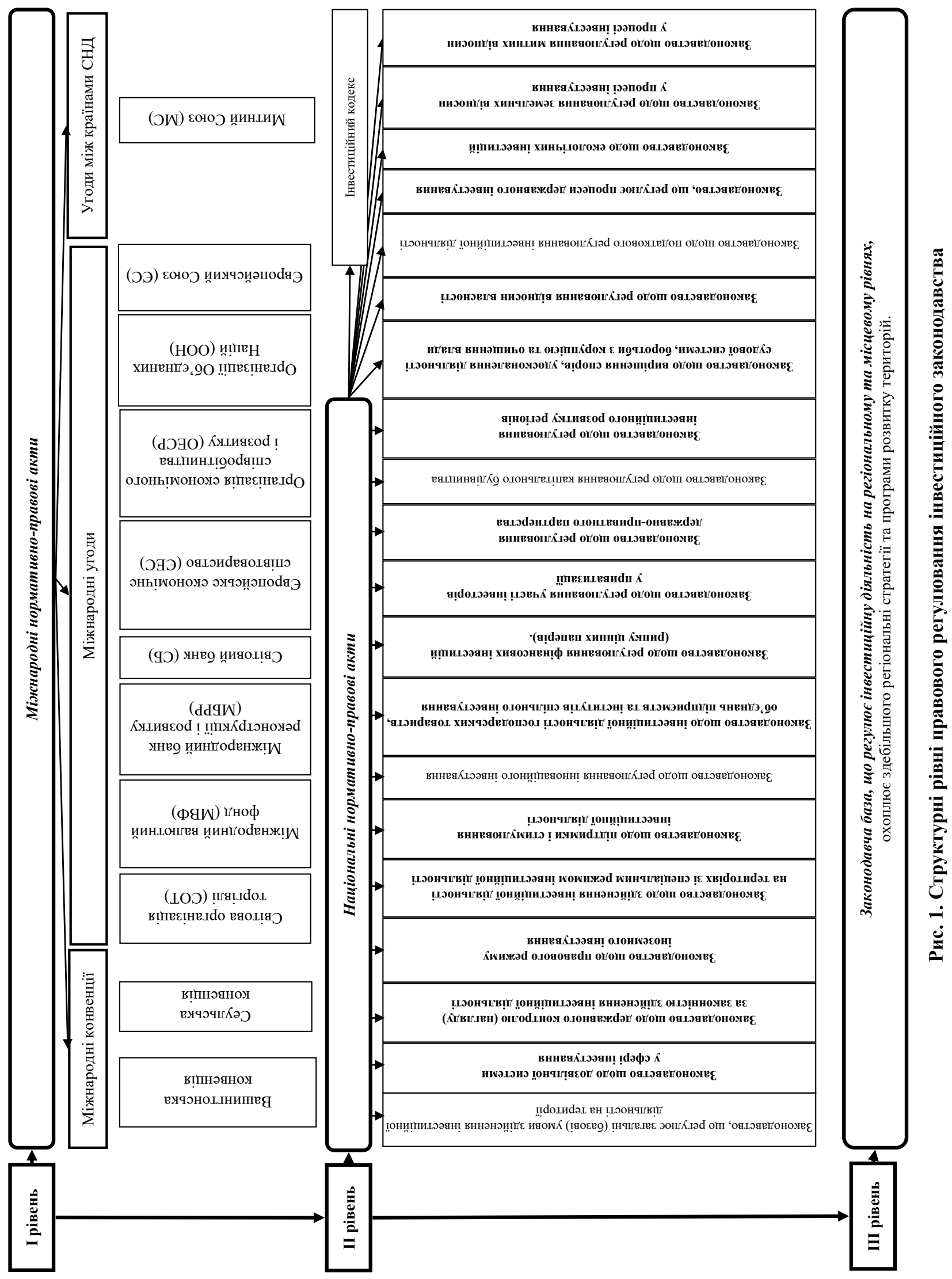


Як член СОТ Україна отримала право використовувати механізм врегулювання суперечок у рамках СОТ, що сприяє справедливому вирішенню будь-яких суперечок із приводу дотримання положень угод СОТ, які можуть виникнути у країни 3 iii торговими партнерами. У рамках зазначеного механізму було позитивно вирішено низку важливих питань, а саме дискримінаційного оподаткування, ліцензування деяких видів української продукції. Україна продовжує використовувати цей механізм СОТ, оскільки це є частиною системних зусиль, спрямованих на забезпечення та розширення присутності українських товарів на інших ринках.

У рамках СОТ міститься ряд норм, які поширюють свою дію на відносини, що випливають 3 інвестиційної діяльності за участю іноземних інвесторів. Насамперед, такі норми містяться в Генеральній угоді про торгівлю послугами у 1994 p. (ГАТС) і в Угоді про зв'язані з торгівлею інвестиційні заходи у 1994 р. (ТРІМС). Крім того, 3-поміж таких актів слід назвати і Угоду про торговельні аспекти прав інтелектуальної власності у 1994 p. (ТРІПС).

Аналізуючи норми правових актів, що діють у рамках СОТ, слід зазначити, що відповідні норми, що стосуються іноземних інвестицій, спрямовані в основному на встановлення правил допуску на ринок, а також на лібералізацію іноземних капіталовкладень.

Надаючи право державам самим визначати сектори економіки, які вони вирішили виключити iз сфери застосування національного режиму або режиму найбільшого сприяння, СОТ тим самим послаблює положення іноземних інвесторів порівняно з нормами міжнародного права i, варто зауважити, прагне до встановлення загального єдиного для всіх учасників правового режиму іноземних інвестицій.

У зв'язку з цим слід зазначити, що в доктрині загалом позитивно сприймається вступ України до СОТ, оскільки така участь дає Україні низку переваг, які проявляються і в сфері іноземних інвестицій. Йтиметься не про надання різних пільг або будь-яких субсидій, а про стабільність режиму економічної діяльності загалом, у тому числі у сфері прогнозування управління економікою з боку державних органів.

В умовах наростаючого вільного руху капіталів внутрішня політика європейських країн дедалі більш взаємодіє з інвестиційною політикою ЄС. Останне виступає як гарант і як загальний «правовий стандарт» для національних інвестицій- них законодавств. При цьому основним принципом виступає те, що імплементація міжнародних інвестиційних норм у національному праві можлива лише, якщо інвестиційне законодавство тієї чи іншої держави відповідає міжнародному інвестиційному праву.

Реалізація загальноприйнятих на багатосторонній і двосторонній основі міжнародних та інвестиційних норм вимагає близьких і аналогічних, однотипних правових норм у національному інвестиційному законодавстві. Така взаємодія, своєю чергою, сприяє зближенню і уніфікації всередині державних інвестиційних норм.

Говорячи про міжнародну договірну уніфікацію норм і стандартів, варто зазначити, що ця форма взаємодії $є$ однією з важливих умов здійснення глобальної економічної інтеграції.

Зобов'язання держав-членів ЄС слідувати певним напрямам (принципам) регулювання $\epsilon$, на наш погляд, одним з основних і ефективних способів уніфікації в області регулювання зовнішньоекономічної діяльності та іноземних інвестицій. Міжнародно-договірна уніфікація норм та стандартів, заснована на зобов'язанні держави у процесі розробки національного законодавства дотримуватися встановлених у міжнародному договорі принципів регулювання, що і $є$ гармонізацією законодавства.

У рамках таких міжнародних організацій, як Європейське Економічне Співтовариство (СЕС) і Організація економічного співробітництва і розвитку (ОЕСР), був створений певний механізм регулювання транснаціонального руху капіталів, що сприяло вдосконаленню механізму регулювання іноземних інвестицій на багатосторонній основі. У 1949 р. був опублікований проект кодексу «справедливого режиму для іноземних інвестицій» у продовження розпочатої в 1931 р. компанії щодо укладення міжнародної конвенції, що гарантує право приватної власності іноземних інвесторів. У 1957 р. Німецьке товариство із заохочення і захисту іноземних інвестицій опублікувало проект Кодексу, що має назву «Міжнародна конвенція взаємного захисту прав приватної власності в іноземних державах».

При цьому універсальні норми і положення, прямо або побічно регламентують правовий режим іноземних інвестицій, закладені, зокрема, в міжнародно-правових актах Світової організації торгівлі, статутах Міжнародного валютного фонду і Світового банку, модельних кодекcax OECP, документах неурядових фінансових організацій, що знаходяться під егідою Лондон- 
ського і Паризького клубів, а також в універсальних фінансових конвенціях, прийнятих у рамках міжнародних економічних організацій, таких як УНІДРУА, ЮНСІТРАЛ, ЮНІДО, ЮНКТАД та ін.

На відміну від європейських країни, що розвиваються, допускають існування загальних принципів міжнародного права, які незалежно від будьякої конвенції, зобов'язують державу, на території якої здійснюються інвестиції, поважати міжнародні стандарти. Формально ці загальні принципи були встановлені виключно під впливом розвинених країн, у той час як країни, що розвиваються, тоді ще не домоглися міжнародного визнання свого суверенітету. По суті загальні принципи, беручи до уваги умови їх розробки, не відображають волю всіх членів світової спільноти, бо вони не сприятливі для країн, що розвиваються.

Особливу роль у поліпшенні інвестиційного клімату відіграє, зокрема, співпраця країн Митного союзу з питань надання митних пільг іноземним інвесторам. Акти, прийняті в рамках Митного союзу i, насамперед, Митний кодекс Митного союзу декларують привілейований статус іноземних інвесторів, встановлюють режим найбільшого сприяння і надають різні правові гарантії.

Об’єктивно Україна зацікавлена у поглибленій економічній взаємодії з країнами Митного союзу, оскільки основою зацікавленості у співпраці 3 членами Митного союзу є стратегічні економічні інтереси України.

Разом із тим Україна зацікавлена у поглибленні інтеграції з Європейським Союзом, що відображено в законодавстві та Конституції України.

Таким чином, завдання створення умов для сталого економічного розвитку потребує адекватної зовнішньоекономічної стратегії, що давала би відповіді на питання, пов'язані із виробленням відповідного позиціонування держави в міжнародному поділі праці. Зокрема, великої ваги набуває визначення того, які вигоди матиме та з якими ризиками зустрінеться Україна, реалізувавши альтернативні сценарії взаємодії з Митним союзом.

Говорячи про міжнародні та європейські стандарти інвестиційної політики загалом, не можна обійти увагою також таке джерело міжнародного права, як звичай. Звичай міжнародного інвестиційного права розглядається як стійке правило, що застосовується в інвестиційній діяльності, яке має міжнародний характер, при цьому володіє всіма рисами юридичної загальнообов'язковості.

Як приклади звичаїв міжнародної торгівлі та звичаїв ділового обороту прийнято називати положення, які уніфіковані Міжнародною торго- вою палатою і отримали назву INCOTERMS 2010. Такі правила не мають обов'язкової юридичної сили і можуть застосовуватися у відносинах сторін тільки в тих випадках, коли сторони в умовах договору передбачили їх застосування, а також у тих випадках, коли міжнародно-правовим актом або відповідним національним актом їм надана обов'язкова юридична сила.

3 цієї точки зору науковий інтерес становить Резолюція Генеральної Асамблеї Організації Об'єднаних Націй із проблем інвестицій № 1803 (XVII) від 14 грудня 1962 р. «Про невід'ємний суверенітет над природними ресурсами» і Резолюція Генеральної Асамблеї ООН № 3201 (XXIX) від 12 грудня 1974 р. «про економічні права та обов'язки держав».

Саме в названих документах ООН відображена політика більшості країн щодо висловлювання принципу встановлення державного суверенітету в області правового регулювання інвестиційних відносин за участю іноземного елемента на національному рівні. У зв'язку з цим виникає питання про правову природу зазначених у названих резолюціях принципах: чи мають вони характер звичайних норм міжнародного права або $є$ рекомендаційними актами і свідчать лише про те, яким має бути міжнародне інвестиційне право.

У зв'язку з цим варто пояснити, що прийнята позиція щодо подібних документів ООН полягає в тому, що вони мають рекомендаційний (необов'язковий) характер і спрямовані на надання допомоги у формуванні норм звичайного міжнародного права, а також на підтвердження чинних відповідних норм. Однак у рішенні цього питання необхідно виходити 3 того, що держави, які взяли відповідні резолюції, мають намір слідувати вираженим у цих пунктах положенням у процесі прийняття національного інвестиційного законодавства і встановлення правового режиму іноземних інвестицій.

Безсумнівно, що не останнє місце в регулюванні інвестиційної діяльності за участю іноземних інвесторів займає національне законодавство.

Висновки. Обгрунтування необхідності будь-якої кодифікації законодавства у сфері господарських правовідносин логічно передбачає встановлення її політичних, економічних та техніко-юридичних завдань [1]. До політичних завдань кодифікації інвестиційного законодавства належить інтеграція національного правового інвестиційного порядку до міжнародної системи функціонування інвестиційного ринку та його правового регулювання 3 максимально 
можливим забезпеченням національних інтересів в інвестиційній сфері [2]. До економічних завдань кодифікації інвестиційного законодавства належать: створення дієвого, законодавчо закріпленого механізму формування та реалізації інвестиційної політики держави, стимулювання інвестиційних процесів із боку національних та іноземних учасників інвестиційної діяльності шляхом закріплення та стабілізації правового інвестиційного порядку на модернізованій законодавчій основі. До техніко-юридичних завдань кодифікації інвестиційного законодавства Укра- їни належать: подолання колізій, повторень, усунення застарілих положень, встановлення єдиних універсальних принципів правового регулювання інвестиційних відносин та гарантій, що надаються їх учасникам; врахування особливостей системно-структурного співвідношення підгалузевої кодифікації інвестиційного законодавства, що пропонується, з існуючими джерелами законодавства України, що має відбуватися через визначення місця такої кодифікації у форматі вертикальних, горизонтальних та діагональних «взаємин» між цими джерелами.

1. Кабрияк Р. Кодификации. Москва, 2007. 476 с.

2. Кудрявцева В.В. Концептуальні засади кодифікації інвестиційного законодавства України. Державне будівництво та місиеве самоврядування. 2009. URL: http://dspace.nulau.edu.ua:8088/ bitstream/123456789/2558/1/Kudryavtseva_175.pdf. (дата звернення: 15.08.2019).

\section{Marukhlenko O.V. WORLD EXPERIENCE IN THE FIELD OF INVESTMENT POLICY}

The article presents the results of the study of international experience in the field of investment policy and the creation of tools for the formation and development of the investment potential of the territory. The influence of investment potential improvement instruments on its constituent elements has been determined. The positive and negative sides of the impact of the instruments on the investment component of the territory are highlighted. The analysis of the state investment policy, conducted in the countries with market economy, shows that, as a rule, it is not limited only to the creation of general conditions of investment activity, but assumes an active role of the state in creating a system of long-term financing of the economy. In many developed countries, including EU states, although they make stringent requirements for foreign states to minimize state interference in the economy, they themselves pursue an active state protectionist policy. This is because the solution of a number of investment problems set by the state inevitably requires such intervention. The state financing of the economy abroad is carried out by means of various, including program-targeted, methods and is distributed across different sectors of the economy, for which different types of special state financial institutions are used.

In the context of uncertainty, increasing volatility in global development trends, the activation of factors contributing to the sustainability and competitiveness of national economies is of particular relevance. Among them are volume increase, rationalization of structure, diversification of sources, substantiation of priority directions and mechanisms of attraction and efficient use of investment resources, which are formed in the institutional sectors of the Ukrainian economy and beyond. The general government sector performs special functions in the investment process - its regulator and investor. Ukraine is now on the path to European integration, which requires the use of topical approaches and priorities on a global scale to the development of the state investment policy and the formation of priorities of the state investment expenditures. Thus, the state investment policy of Ukraine should include the basic aspects of the main goals and objectives of the new generation investment policy, taking into account the latest trends and needs of the world economy. As economic processes in Ukraine are reforming in accordance with European standards, it is important to consider generalizations of foreign experience in the formulation and implementation of state investment policy.

Key words: investment policy, legal acts, state, convention, agreement, standards. 